\title{
Ecological Study on Ambient Air Quality, Green Open Space, And Acute Respiratory Infection in Depok City Year 2013-2017
}

\author{
Aulia Rahman ${ }^{1}$, Suyud Warno Utomo ${ }^{2}$ \\ \{Auliarahmanskm@gmail.com ${ }^{1}$ \} \\ Faculty of Public Health, Universitas Andalas ${ }^{1}$, Faculty of Public Health, Universitas Indonesia ${ }^{2}$
}

\begin{abstract}
Acute Respiratory Infection (ARI) disease is still the highest number of diseases in Depok City. The decline in ambient air quality and availability of Green Open Space (GOS) due to the growing development is thought to be the causing factor. This study was conducted to determine the trend of Ambient Air Quality, GOS, and the number of ARI cases that occurred in Depok during 2013-2017. The research design is an ecological study. The units of analysis are the secondary data of the concentration of five parameters of ambient air quality $\left(\mathrm{SO}_{2}, \mathrm{NO}_{2}, \mathrm{CO}, \mathrm{Pb}\right.$ dan $\left.\mathrm{PM}_{10}\right)$ and $\mathrm{GOS}$ from the Department of Hygiene and Environment and data of ARI cases from Health Department in Depok. The analysis was done with spatial and statistical analysis. The result of the analysis showed in tables, graphs, and mapping. There is a random fluctuating trend on the ambient air parameters and ARI. Whereas there is a patterned increase on the GOS. It is suggested to the city government as well as the official departments in Depok City to formulate regulations and various programs to improve the quality of environmental health and reduce the number of ARI cases in Depok.
\end{abstract}

Keywords: Ambien Air Quality, Green Open Space, Acute Respiratory Infection, Air Pollution, Greening.

\section{Introduction}

Air pollution that occurred in Indonesia is increasingly alarming. The results of air quality monitoring conducted by Greenpeace since January 2017 in 21 locations in Jakarta, Bogor, Depok, Tangerang, and Bekasi city (Jabodetabek) showed that air quality in Jabodetabek over the past six months has indicated unhealthy for human. It also might have more serious health impacts on sensitive groups, such as children, pregnant women, and the elderly group [1].

The development that is developing today throughout the world, especially in the fields of industry and technology, followed by an increase in population, causes changes in the composition of normal air. If the change in air composition exceeds the carrying capacity of the environment, pollution will be occurred [2]. According to Government Regulation No. 41 of 1999, Air Pollution is the entry or insertion of substances, energy or other components into ambient air by human activities, so that ambient air quality drops to a certain level, which causes ambient air cannot fulfill its function [3]. National ambient air quality standard that includes 13 parameters contained in attachment PP no. 41 of 1999. The thirteen parameters are $\mathrm{SO}_{2}, \mathrm{CO}$, $\mathrm{NO}_{2}, \mathrm{O}_{3}, \mathrm{HC}, \mathrm{PM}_{10}, \mathrm{PM}_{2,5}, \mathrm{TSP}, \mathrm{Pb}$, Dustfall, Total Fluorides, Flour Indeks, Chlorine, and Chlorine Dioxide, and also Sulphate [4]. 
The effects of air pollution include reducing air quality, triggering global warming and the greenhouse effect, depletion of the ozone layer, acid rain, changes in the balance of the ecosystem, and cause various health problems in humans. The problems can be hypersensitivity, heart, headache, pain, eye pain, low intellectual growth, disorders of the reproductive system, and, most importantly, respiratory systems disorders such as asthma, bronchitis, and acute respiratory infections (ARI) [5].

According to the World Health Organization (WHO), Acute Respiratory Infection (ARI) is an upper or lower respiratory tract disease, which can cause a variety of diseases ranging from asymptomatic or mild infections to severe and severe illnesses. It is deadly, depending on the causative pathogen, environmental factors, and host factors. Until now, ARI is still one of the main causes of disease morbidity and mortality in the world. Nearly four million people die from ARI every year. The mortality rates are very high in infants, children, and older people, especially in countries with low and medium-income per capita [6].

Based on the results of the Basic Health Research conducted by the Ministry of Health of the Republic of Indonesia in 2013, it is known that the prevalence of ARI in Indonesia is $25.0 \%$. Over the last few years, ARI is still one of the five diseases, with the most cases recorded in Indonesia [7]. In West Java, the incidence and prevalence of ARI in 2013, according to Basic Health Research in the same year, was 1.9 percent (National 1.8\%) and 4.9 percent (National 4.5\%). Meanwhile, according to Depok City Health Department data, the prevalence of ARI in Depok, which was recorded in outpatients in all Depok hospitals in 2016 , reached $23.29 \%$ or as many as 41,686 cases. Then the prevalence of ARI in Depok city recorded in the outpatient department in all Puskesmas in Depok city reached 122,407 cases. Risk factors contributing to the ARI case include poor nutrition, low exclusive breastfeeding, air pollution, density, low birth weight, and low immunization coverage [8][9].

The initial step to overcome this problem is the existence of adequate air quality monitoring in the form of an adequate number and distribution of monitoring locations, which are easily accessible to the community. Then, a comparison can be made between the air quality and the availability of Green Open Space (GOS) as a balancing unit for urban ecosystems that filters and cleans urban air from various pollutants, in addition to maintaining groundwater availability and seepage for rainwater absorption [10]

Various comparative measurements showed that large cities with high population density. By high socioeconomic activities and green open spaces are decreased because they have been eroded by the construction of settlements, regional infrastructure and facilities, office buildings, and industrial areas that have air quality lower than other cities [4].

By knowing the air quality condition, ARI, and the broad conditions of Green Open Space, we can identify the patterns informing when pollution levels are high, when the green open space is good, etc. It might be used by governments as consideration to formulate various mitigation policies [11]

\section{Method}

This research was conducted using an ecological study design and using secondary data. This research was conducted in Depok City, West Java province, during 2018. The analysis used the value data of five ambient air quality parameters $\left(\mathrm{SO}_{2}, \mathrm{NO}_{2}, \mathrm{CO}, \mathrm{Pb}\right.$, and $\left.\mathrm{PM}_{10}\right)$ which measured once a year by the Sanitation and the Environmental Department of The Depok City during 2013-2017, Green Open Space data for 2013-2017, and data on reports on the number of cases of Acute Respiratory Infection (ARI) recorded at the Depok City Health Office during 2013-2017. The analysis was performed with SPSS software, and The mapping was made by 
using Quantum Geographic Information System software. The result shows the frequency distribution table and the design of the dynamics change map for each variable.

\section{Result}

Ambient Air Quality can be seen from the concentration/levels of pollution parameters that enter into it.

Table 1. Frequency of Concentration of Ambient air quality parameters in eleven Districts in Depok City in 2013-2017

\begin{tabular}{|c|c|c|c|c|c|c|}
\hline \multirow{2}{*}{ Districts } & \multirow{2}{*}{ Year } & \multicolumn{5}{|c|}{ Concentration $\left(\mu \mathrm{g} / \mathrm{Nm}^{3}\right)$} \\
\hline & & $\mathrm{SO}_{2}$ & $\mathrm{NO}_{2}$ & $\mathrm{CO}$ & $\mathbf{P b}$ & $\mathbf{P M}_{10}$ \\
\hline \multirow{5}{*}{ Sawangan } & 2013 & 82,5 & 44,4 & 1995 & 0,01 & 135 \\
\hline & 2014 & 54,3 & 27,9 & 1140 & 0,01 & 131 \\
\hline & 2015 & 60,8 & 19,5 & 1140 & 0,01 & 82,1 \\
\hline & 2016 & 57,4 & 19,8 & 1140 & 0,05 & 82 \\
\hline & 2017 & 47,90 & 26,3 & 185 & 0,05 & 0,97 \\
\hline \multirow{5}{*}{ Bojongsari } & 2013 & 75,5 & 30,5 & 1520 & 0,01 & 131 \\
\hline & 2014 & 55,6 & 25 & 1140 & 0,01 & 90,3 \\
\hline & 2015 & 171 & 28,1 & 1140 & 0,01 & 65 \\
\hline & 2016 & 52,3 & 21,8 & 1140 & 0,052 & 98,3 \\
\hline & 2017 & 47,90 & 26,3 & 185 & 0,05 & 0,7 \\
\hline \multirow{5}{*}{ Pancoran Mas } & 2013 & 80 & 50,7 & 5700 & 0,01 & 123 \\
\hline & 2014 & 46,8 & 20,7 & 1140 & 0,003 & 176 \\
\hline & 2015 & 67,2 & 22,7 & 1140 & 0,01 & 41 \\
\hline & 2016 & 87 & 24,5 & 1140 & 0,010 & 48 \\
\hline & 2017 & 47,90 & 98,8 & 981,9 & 0,05 & 1,46 \\
\hline \multirow{5}{*}{ Cipayung } & 2013 & 50,2 & 40,1 & 1140 & 0,01 & 114 \\
\hline & 2014 & 58 & 28,3 & 1140 & 0,019 & 95 \\
\hline & 2015 & 147 & 63,3 & 1140 & 0,01 & 85 \\
\hline & 2016 & 85,2 & 11,4 & 1140 & 0,010 & 91 \\
\hline & 2017 & 47,9 & 26,3 & 185 & 0,05 & 21,4 \\
\hline \multirow{5}{*}{ Sukmajaya } & 2013 & 42,8 & 34,5 & 3420 & 0,01 & 84 \\
\hline & 2014 & 61,7 & 29,5 & 1140 & 0,01 & 104 \\
\hline & 2015 & 47,5 & 16,5 & 1140 & 0,01 & 54 \\
\hline & 2016 & 52 & 21,9 & 1140 & 0,078 & 83,2 \\
\hline & 2017 & 47,90 & 26,3 & 1350,62 & 0,074 & 2,95 \\
\hline \multirow{5}{*}{ Cilodong } & 2013 & 88,1 & 75,9 & 1710 & 0,01 & 76 \\
\hline & 2014 & 56 & 28,6 & 1140 & 0,36 & 51 \\
\hline & 2015 & 60,3 & 24,7 & 1140 & 0,01 & 88 \\
\hline & 2016 & 51,6 & 3,02 & 1140 & 0,010 & 103 \\
\hline & 2017 & 47,9 & 30,03 & 573,6 & 0,05 & 1,24 \\
\hline \multirow{5}{*}{ Cimanggis } & 2013 & 40,1 & 21,1 & 10260 & 0,01 & 105 \\
\hline & 2014 & 83,9 & 30,3 & 1140 & 0,11 & 76 \\
\hline & 2015 & 59,5 & 21,5 & 1140 & 0,01 & 81 \\
\hline & 2016 & 84,1 & 5,36 & 1140 & 0,010 & 144 \\
\hline & 2017 & 47,90 & 46,14 & 310,05 & 0,05 & 23,2 \\
\hline
\end{tabular}




\begin{tabular}{|c|c|c|c|c|c|c|}
\hline \multirow{2}{*}{ Districts } & \multirow{2}{*}{ Year } & \multicolumn{5}{|c|}{ Concentration $\left(\mu \mathrm{g} / \mathrm{Nm}^{3}\right)$} \\
\hline & & $\mathrm{SO}_{2}$ & $\mathrm{NO}_{2}$ & $\mathrm{CO}$ & $\mathbf{P b}$ & $\mathbf{P M}_{10}$ \\
\hline \multirow{5}{*}{ Tapos } & 2013 & 46,4 & 35,5 & 3094 & 0,01 & 279 \\
\hline & 2014 & 73,6 & 46,2 & 1140 & 0,085 & 67 \\
\hline & 2015 & 80 & 32,1 & 1140 & 0,01 & 117 \\
\hline & 2016 & 63,9 & 19,1 & 1140 & 0,042 & 84,2 \\
\hline & 2017 & 47,9 & 26,3 & 431,5 & 0,05 & 1,55 \\
\hline \multirow{5}{*}{ Beji } & 2013 & 50,2 & 40,1 & 1140 & 0,01 & 114 \\
\hline & 2014 & 59,2 & 28,4 & 1140 & 0,01 & 138 \\
\hline & 2015 & 205 & 26,7 & 1140 & 0,01 & 102 \\
\hline & 2016 & 38,2 & 22,1 & 1140 & 0,078 & 102 \\
\hline & 2017 & 47,90 & 73,8 & 1031,85 & 0,109 & 3,84 \\
\hline \multirow{5}{*}{ Limo } & 2013 & 72,9 & 42,1 & 1710 & 0,01 & 185 \\
\hline & 2014 & 56,7 & 25,3 & 1140 & 0,01 & 144 \\
\hline & 2015 & 56,3 & 20,6 & 1140 & 0,01 & 71 \\
\hline & 2016 & 58 & 25,3 & 1140 & 0,010 & 85 \\
\hline & 2017 & 47,9 & 26,3 & 775 & 0,05 & 8,8 \\
\hline \multirow{5}{*}{ Cinere } & 2013 & 69,6 & 47,5 & 1425 & 0,01 & 185 \\
\hline & 2014 & 55,8 & 23 & 1140 & 0,01 & 112 \\
\hline & 2015 & 165 & 67,4 & 1140 & 0,01 & 101 \\
\hline & 2016 & 98,3 & 18,2 & 1140 & 0,010 & 55 \\
\hline & 2017 & 47,9 & 25,28 & 465,5 & 0,05 & 8,8 \\
\hline
\end{tabular}

Table 1 shoed the frequency concentrations of five ambient air quality parameters which are the research variables $\left(\mathrm{SO}_{2}, \mathrm{NO}_{2}, \mathrm{CO}, \mathrm{Pb}\right.$, and $\left.\mathrm{PM}_{10}\right)$ measured in eleven sub-districts (Sawangan, Bojongsari, Pancoran Mas, Cipayung, Sukmajaya, Cilodong, Cimanggis, Tapos, Beji, Beji, Limo and Cinere) in Depok City during 2013-2017.
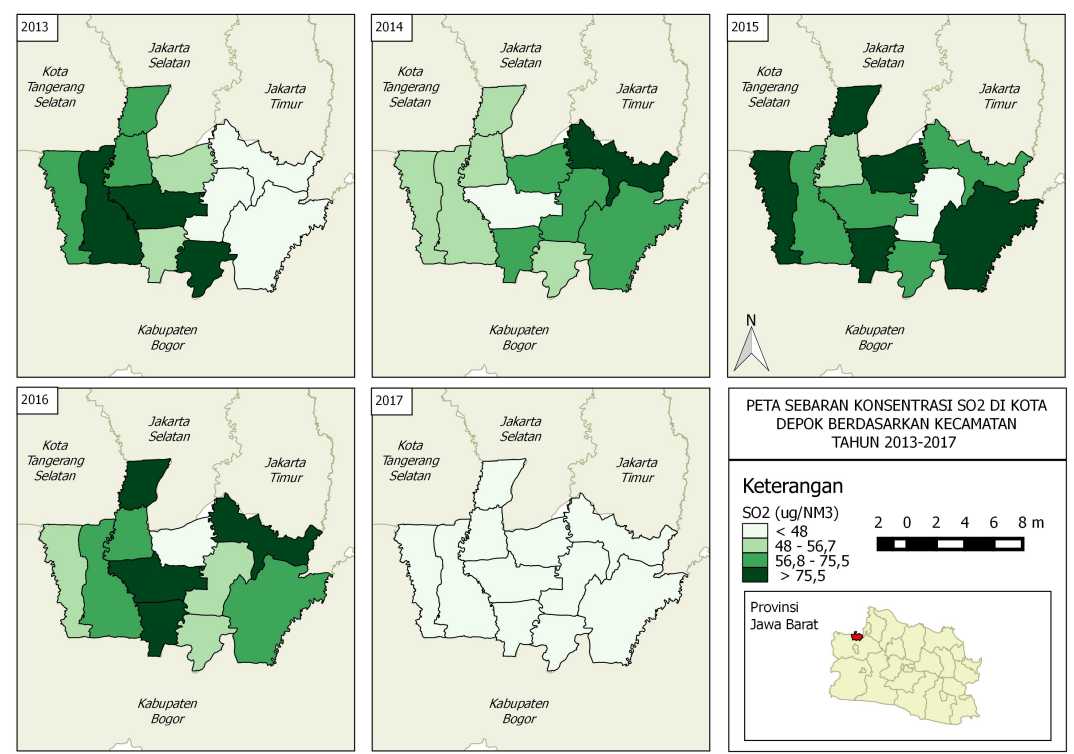

Figure 1. Map of Dynamic Change of $\mathrm{SO}_{2}$ Concentration Based on Districts in Depok in 2013-2017 
Based on figure 1 , it can be concluded that the concentration of $\mathrm{SO}_{2}$ has been changing randomly in every subdistrict. In some districts, the concentration has been increasing or decreasing randomly every year, while the other one has been constant. In 2017, the concentration was not well measured because of the new laboratory, resulted in the homogeneous data.
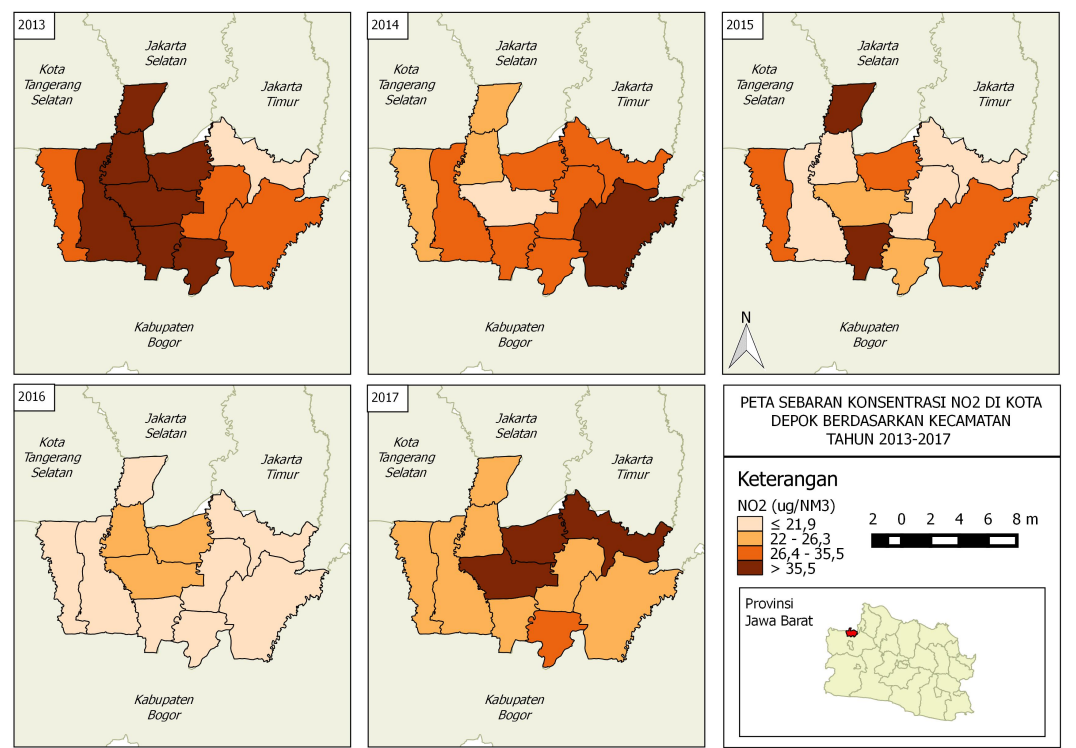

Figure 2. Map of Dynamic Change of $\mathrm{NO}_{2}$ Concentration based on Districts in Depok 2013-2017

Based on figure 2, it can be concluded that the concentration of $\mathrm{NO}_{2}$ has been changing randomly in every subdistrict. In some districts, the concentration has been increasing or decreasing randomly every year, while the other one has been constant.
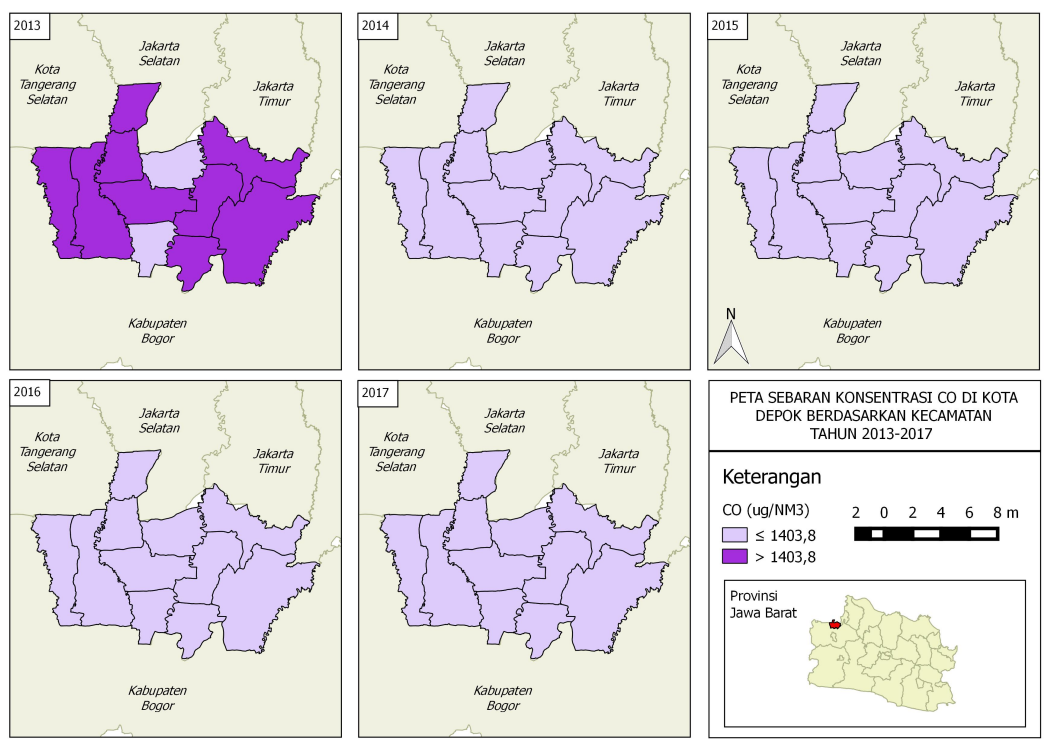

Figure 3. Map of Dynamic Change of CO Concentration based on Districts in Depok 2013-2017 
Based on figure 3, it can be concluded that the concentration of $\mathrm{CO}$ has not been changing in every subdistrict since 2014 . The laboratory workers assume that since 2013 , the park in the city already succeeds in reducing $\mathrm{CO}$ concentration in the city under the limit based on the regulation [12].
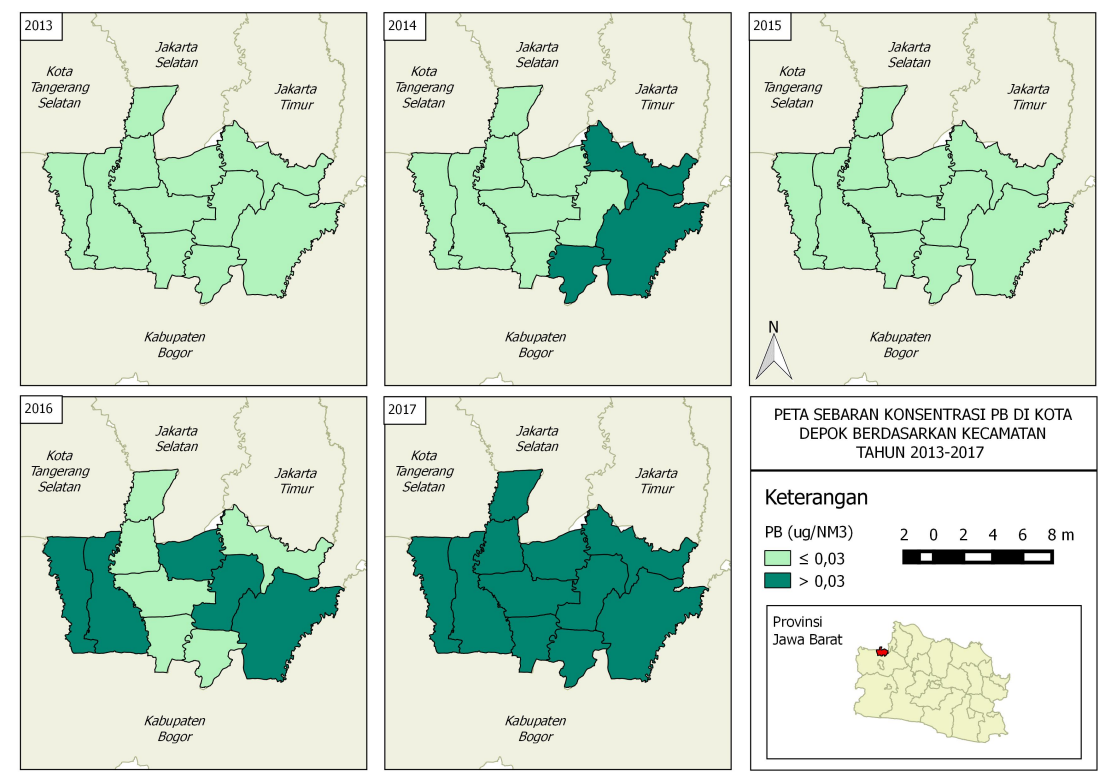

Figure 4. Map of Dynamic Change of PB Concentration based on Districts in Depok 2013-2017

Based on figure 4, it can be concluded that the concentration of PB has been changing randomly in every subdistrict. In some districts, the concentration has been increasing or decreasing randomly every year, while the other one has been constant. In 2017, the concentration on the whole districts had no differences. It is also similar for 2013 and 2015.
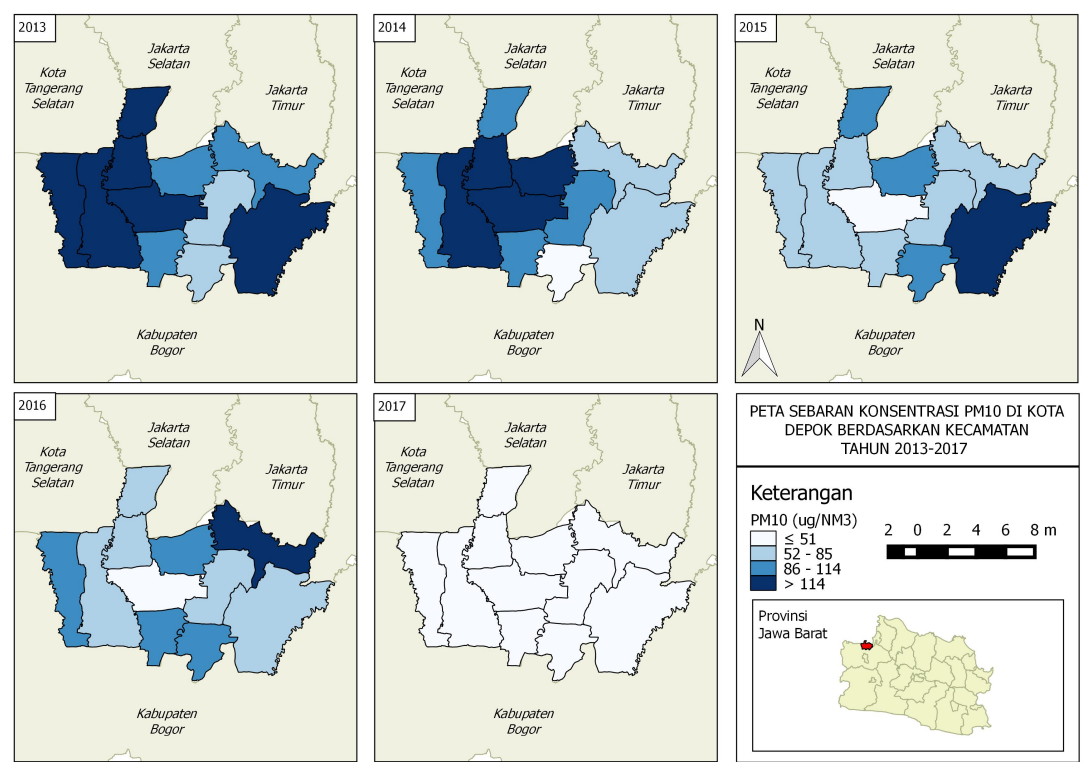

Figure 5. Map of Dynamic Change of $\mathrm{PM}_{10}$ Concentration based on Districts in Depok 2013-2017 
Based on figure 5, it can be concluded that the concentration of $\mathrm{PM}_{10}$ has been changing randomly in every subdistrict. In some districts, the concentration has been increasing or decreasing randomly every year, while the other one has been constant. In 2017, the concentration was constant in all of the subdistricts.

The number of cases of acute respiratory infections (ISPA) in the city of Depok has changed every year during 2013-2017. The development of the number of ARI cases can be seen in the table of annual cases as follows.

Table 2. Frequency of Number of ARI Cases in Depok City in 2013-2017

\begin{tabular}{cc}
\hline Year & Number of ARI cases \\
\hline Year 2013 & 868.846 \\
Year 2014 & 247.481 \\
Year 2015 & 107.908 \\
Year 2016 & 166.311 \\
Year 2017 & 158.941 \\
\hline
\end{tabular}

Table 2 showed the number of Acute Respiratory Infection (ARI) in the Depok city in 20132017. Based on the table, it can be concluded that the number of cases has been decreasing since 2013 to recent.

Table 3. Frequency of Parks Area in Depok City 2013-2017

\begin{tabular}{lccccc}
\hline \multirow{2}{*}{ Green open Space } & \multicolumn{5}{c}{ Wide Area $\left(\mathbf{m}^{\mathbf{2}}\right)$} \\
\cline { 2 - 6 } & $\mathbf{2 0 1 3}$ & $\mathbf{2 0 1 4}$ & $\mathbf{2 0 1 5}$ & $\mathbf{2 0 1 6}$ & $\mathbf{2 0 1 7}$ \\
\hline Village Level Park & 13.500 & 81.403 & 97.457 & 107.354 & 111.404 \\
Path Park & 40.530 & 48.530 & 55.530 & 56.349 & 57.596 \\
Middle street Park & 1.400 & 1.400 & 1.400 & 1.400 & 1.400 \\
RT/RW Park & 3.100 & 7.063 & 12.531 & 26.878 & 47.505 \\
Arboretum & 2.000 & 2.000 & 2.000 & 2.000 & 2.000 \\
Forerst park (Tahura) & 71.559 & 71.559 & 71.559 & 71.559 & 71.559 \\
\hline
\end{tabular}

Table 3 showed the frequency of parks area in the Depok city in 2013-2017. Based on the table, it can be concluded that the number of cases has been decreasing since 2013 to recent

\section{Discussion}

The average $\mathrm{SO}_{2}$ concentration in Depok City for the past five years was $67.889 \mu \mathrm{g} / \mathrm{Nm}^{3}$, with the lowest concentration being $38.20 \mu \mathrm{g} / \mathrm{Nm}^{3}$ recorded in 2016 in Beji District, and the highest concentration was $205 \mu \mathrm{g} / \mathrm{Nm}^{3}$ recorded in Beji District in 2015. The $\mathrm{SO}_{2}$ concentrations recorded in 2017 are constant / the same for all districts, which is below $47.9 \mu \mathrm{g}$ $/ \mathrm{Nm}^{3}$.

According to the Republic of Indonesia Government Regulation related to Air Pollution Control [12], the quality standard for $\mathrm{SO}_{2}$ parameter concentration is $365 \mu \mathrm{g} / \mathrm{Nm}^{3}$. In other words, $\mathrm{SO}_{2}$ concentrations recorded in Depok City in 2013-2017 are still below the quality standard, so that it can still be said to be not harmful to public health. Map distribution of $\mathrm{SO}_{2}$ Concentrations by Sub-District in Depok City in 2013-2017 shows that the average $\mathrm{SO}_{2}$ concentration in each sub-district experienced random increases and decreases. 
The results showed that the average $\mathrm{NO}_{2}$ concentration in Depok during the last five years was $31.69 \mu \mathrm{g} / \mathrm{Nm}^{3}$, with the lowest concentration being $3.02 \mu \mathrm{g} / \mathrm{Nm}^{3}$ recorded in 2016 in Cilodong District and the highest concentration was $98.8 \mu \mathrm{g} / \mathrm{Nm}^{3}$ which was recorded in Pancoran Mas District in 2017.

According to the Republic of Indonesia Government Regulation related to Air Pollution Control [12], the quality standard for the $\mathrm{NO}_{2}$ parameter concentration is $150 \mu \mathrm{g} / \mathrm{Nm}^{3}$. In other words, the $\mathrm{NO}_{2}$ concentrations recorded in Depok City in 2013-2017 are still below the quality standard, so that it can still be said to be not harmful to public health. Map distribution of $\mathrm{NO}_{2}$ concentrations by the district in Depok in 2013-2017 shows that the average $\mathrm{NO}_{2}$ concentration in each district experienced a random increase and decrease.

The results showed that the average CO concentration in Depok during the last five years was $1403,802 \mu \mathrm{g} / \mathrm{Nm}^{3}$ with the lowest concentration being $185 \mu \mathrm{g} / \mathrm{Nm}^{3}$ recorded in 2017 in Bojong Sari and Cipayung Districts, while the highest concentration was 10,260 $\mu \mathrm{g} / \mathrm{The} \mathrm{Nm}^{3}$ recorded in Cipayung Subdistrict in 2013. The CO concentrations recorded in 2014, 2015, and 2016 were constant / the same for all Subdistricts, namely at $1140 \mu \mathrm{g} / \mathrm{Nm}^{3}$.

According to the Republic of Indonesia Government Regulation related to Air Pollution Control [12], the quality standard for the concentration of CO parameters is $10,000 \mu \mathrm{g} / \mathrm{Nm}^{3}$. In other words, the concentration of CO recorded in several sub-districts in Depok in 2013-2017 still exceeded the quality standard. It can be said that pollution caused by $\mathrm{CO}$ can cause disruption to public health in 2013, so it can also be suspected as an important factor cause of the high number of cases of upper respiratory tract infections (ARI) in the same year. Map of distribution of CO concentrations by the district in Depok in 2013-2017 shows that the average CO concentration was very high in 2013 , but in subsequent years it tends to be constant in all districts.

The results showed that the average $\mathrm{Pb}$ concentration in Depok during the last five years was $0.034 \mu \mathrm{g} / \mathrm{Nm}^{3}$ with the lowest concentration being $0.01 \mu \mathrm{g} / \mathrm{Nm}^{3}$ which was recorded the same in all Sub-districts in 2013 and 2015, while the highest concentration was $0.36 \mu \mathrm{g} / \mathrm{Nm}^{3}$ recorded in Cilodong Subdistrict in 2014. The Pb concentrations recorded in 2013 and 2015 are constant / the same for all Subdistricts, namely at $0.01 \mu \mathrm{g} / \mathrm{Nm}^{3}$.

According to the Republic of Indonesia Government Regulation related to Air Pollution Control [12], the quality standard for the $\mathrm{Pb}$ concentration parameter is $2 \mu \mathrm{g} / \mathrm{Nm}^{3}$. In other words, the Pb concentration recorded in Depok in 2013-2017 is still below the quality standard, so it can still be said to be safe and not harmful to public health. Map of distribution of $\mathrm{Pb}$ Concentrations by Sub-District in Depok City in 2013-2017 shows that the average $\mathrm{Pb}$ concentration is below the mean during 2013-2015, but has increased in 2016 and 2017. This may be due to the increase in the intensity of mobilization or the use of material fuel oil in the region.

The results showed that the average $\mathrm{PM}_{10}$ concentration in Depok during the last five years was $84.60 \mu \mathrm{g} / \mathrm{Nm}^{3}$, with the lowest concentration being $0.7 \mu \mathrm{g} / \mathrm{Nm}^{3}$ recorded in Bojongsari District in 2017, while the highest concentration was $279 \mu \mathrm{g} / \mathrm{Nm}^{3}$ which was recorded in Tapos District in 2013.

According to the Republic of Indonesia Government Regulation related to Air Pollution Control [12], the quality standard for the concentration of $\mathrm{PM}_{10}$ parameters is $150 \mu \mathrm{g} / \mathrm{Nm}^{3}$. In other words, $\mathrm{PM}_{10}$ concentrations recorded in several sub-districts in Depok in 2013-2017 still exceeded the quality standard, so that it can be said that pollution caused by PM10 can disrupt public health, especially concerning the emergence of Cases of Respiratory Tract Infection Above (ARI).

Map of distribution of $\mathrm{PM}_{10}$ concentrations by the district in Depok in 2013-2017 shows that the average concentration of $\mathrm{PM}_{10}$ is quite high in several districts in 2013-2014. While in 
the following years, the average $\mathrm{PM}_{10}$ concentration has decreased, even becoming much lower in 2017 with a constant rate in all districts (below $51 \mu \mathrm{g} / \mathrm{Nm}^{3}$ ).

The results showed that the area of green open space changed during 2013-2017, with an average of $227,905 \mathrm{~m} 2$. The smallest green space is in 2013, which is 130,089 , and the largest green space in 2017 is $291,464 \mathrm{~m} 2$. The increase in the area of green space, especially at the village level, Track Park, Pulau Pulau Jalan, RT / RW Environmental Park, Arboretum, and Forest Park, increases with the years. However, this number is still very far from the Minimum City Green Space area, according to the law, which is $30 \%$ of the total City area. The area of Depok City is 200,099 m2, which means that a minimum of green space must be $60,000 \mathrm{~m} 2$.

It can occur due to several assumptions. For example, the lack of accuracy in digitizing maps becomes a two-dimensional picture, because aerial photographs from satellite imagery are not taken at the same time, but rather depend on the time taken and the level of air clarity. The accuracy of computer digitizing accuracy can be increased if you can get the Shape File from the Green Open Space (GOS) map. In fact, thus also, the actual extent can be calculated. Unfortunately, in this study, the data was not successful because there were limited data sources from agencies that should have the data.

\section{Conclusion}

There were random changes in the concentration of ambient air quality parameters during 2013-2017. There is no clear trend of decreasing green open space (GOS) in the results of the mapping of green open space in the city of Depok in 2013-2017, although there is an increasing trend in the area of parks and great forests. There are random fluctuations in the distribution map of ambient air quality parameters and the number of ARI cases in Depok in 2013-2017.

\section{Referencess}

[1] Tempo : Depok Pertanyakan Riset Kualitas Udara Green Peace. (Jakarta). (2017).

[2] Mulia, RM. Environmental Health. (Jakarta Barat : Graha Ilmu \& UIEI University Press). (2005).

[3] Mukono, HJ. Air Pollution and The Effect to Respiratory Disorders. (Surabaya : Airlangga University Press). (2003).

[4] Badan Pusat Statistik (BPS). Quality of Environmental Index year 2008. (Jakarta : Badan Pusat Statistik Indonesia). (2010).

[5] Cahyono, T. Air Conditioning. (Yogyakarta : Penerbit Andi Offset). (2017).

[6] WHO. Prevention and Control of Acute Respiratory Infection (ARI) Tending to Epidemic and Pandemic in Health Care Facilities. (2007). Retrieved from http://www.who.int/csr/resources/publications

[7] Depkes RI. Basic Health Research. Jakarta : Kementrian Kesehatan Republik Indonesia. (2013).

[8] Dinas Kesehatan Provinsi Jawa Barat. Health Profile of West Java Province. (2016).

[9] Dinas Kesehatan Kota Depok. City of Depok Health Profile. (2016).

[10] Ludang, Y. Biodiversity of Green Open Space Based on Ulayat Knowledge in Palangkaraya City. Tangerang: An 1mage Publisher. (2017).

[11] Dinas Kebersihan dan Lingkungan Hidup Depok. Profil DKLH. (2015).

[12] Republic of Indonesia Government Regulation (PP RI) No. 41 of 1999 concerning Air Pollution Control. (1999). 